\title{
Environmental diagnosis in areas with different use and occupation using the perception of diverse biological activity
}

\author{
A. I. Ribeiro ${ }^{1}$, A. Peche Filho ${ }^{2}$, G. A. de Medeiros ${ }^{1}$, R. M. Longo ${ }^{3}$, \\ M. Storino ${ }^{2}$, F. H. Fengler ${ }^{2}$, E. M. L. Keller ${ }^{4}$, J. Z. Rapp ${ }^{5} \&$ \\ E. P. Freitas ${ }^{2}$ \\ ${ }^{1}$ Universidade Estadual Paulista, UNESP, Brazil \\ ${ }^{2}$ Instituto Agronômico, IAC, Brazil \\ ${ }^{3}$ Pontificia Universidade Católica de Campinas, PUCCAMP, Brazil \\ ${ }^{4}$ University of Basel, Basel, Switzerland \\ ${ }^{5}$ Freie Universität, Berlin
}

\begin{abstract}
In Brazil, the degradation of soil and landscape by urban and agricultural frontiers expansion leads to the need for comprehensive studies and consider the diverse biological activities generated from different interventions in the landscape, becoming an instrument for assessing the impacts and the decision for its environmental management. The objective of this study was to evaluate the influence of different forms of occupation of the landscape, considering ecological elements and their interactions. The work was carried out on the Instituto Agronômico in the county of Jundiai, in the state of Sao Paulo, Brazil. The area under study has been subjected to different use and occupancy for a period of about 40 years. During this period the landscape has been transformed, with the current scenario can be classified as a degraded area mining; grassy area; Araucaria forest and pasture. These areas were evaluated by means of a transect, from which ten sampling sites were selected for the description of diverse biological activities, which included: evaluation and description of ground cover, identifying the presence of fungus and insect species. Furthermore, we evaluated in these points the $\mathrm{pH}$, fertility and porosity of the topsoil $(0-0.10 \mathrm{~m})$. The results showed a variation of the elements analyzed and a relationship between the use and occupation of land in the different scenarios of
\end{abstract}


the current landscape. The biological activity was more diverse in the Araucaria forest, reflected by the abundance of litter, higher content of organic matter and soil nutrients, demonstrating the effectiveness of the technique for assessing the level of degradation of the landscape used, which is expeditious and inexpensive. Keywords: land degradation, soil restoration, environmental impact.

\section{Introduction}

In Brazil it was observed in the last century, an impressive economic growth of historical singularity, leading to an expansion of its urban and agricultural frontiers.

An important indicator of significant economic growth in Brazil refers to the variation of its gross domestic product, which in 1959 was U.S. \$ 11,760 million (Montoya and Finamore [1]), and in 2010 reached U.S. \$ 2,172,000 million.

Urban growth has been associated with industrialization and rural exodus from the 1950s, caused by a change in subsistence agriculture to export-oriented one (Andrade and Serra [2]). According to the IBGE Demographic Census, in 1950 the urban population was $18,782,891$ of people, and $36.1 \%$ lived in urban areas. With the increasing urbanization of the population, in 1970 , about $56 \%$ of Brazilians lived in cities.

In 2000 the urban population reached $137,755,550$ people, which corresponded to an urbanization rate of $81.2 \%$ (Girardi [3]). In the latest official estimates, in 2010, the Brazilian population reached 190,732,694, of which $84 \%$ was concentrated in cities (IBGE [4]). This fact, together with the expansion of agriculture and mining in Brazil, contributed to a significant degradation of soil and landscape, as pointed out by different authors (Spavorek et al. [5]; Peron and Evangelista [6], Longo et al. [7], Longo et al. [8], Medeiros et al. [9]; Medeiros et al. [10]), leading to the need for comprehensive studies that consider the interaction of ecological factors involved.

In this context, the study based on field observation of ecological relationships between organisms and the environments in which they are inserted, it becomes an important tool for assessing the environmental impacts of human intervention in the landscape, the recovery or level of degradation. A potential of this type of tool, whose methodological approach is described by Bennet and Humpries [11], refers to his character expeditious and inexpensive to analyze environmental impact through diversified biological activity.

In the analysis of diverse biological activities include the observation of the presence and interaction of factors such as vegetation, fauna, microorganisms, soil, drainage, climate, etc.. This approach, by its scope, has been applied in studies of different nature, addressing the evaluation of indicators in environmental studies (Maeder et al. [12], Ramesh and Mathivanan [13]).

This study aims to evaluate the influence of different forms of occupation of a degraded landscape, using a practical and expeditiously methodology with emphasis on visual interpretation and collection of material. 


\section{Material and methods}

\subsection{History and characteristics of the area}

This work was developed at the Center for Engineering and Automation of the Instituto Agronômico (IAC-CEA), in the county of Jundiaí, in the state of Sao Paulo, Brazil, latitude $23^{\circ} 08^{\prime} 53$ "S, longitude $46^{\circ} 55^{\prime} 42^{\prime \prime} \mathrm{W}, 700 \mathrm{~m}$ above sea mean level (Figure 1).

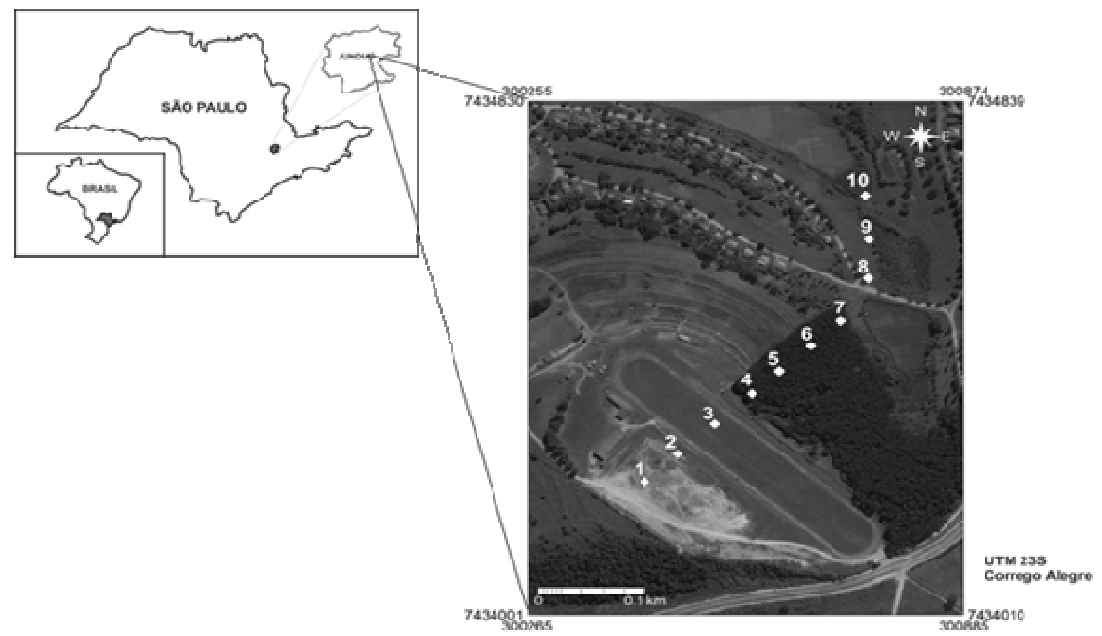

Figure 1: $\quad$ Local e pontos do experimento.

The climate, according to Köppen climate classification, it is a humid subtropical climate (Cwa), corresponding to an altitude tropical climate, with rains in summer and dry in winter. The average annual temperature reaches $20.9{ }^{\circ} \mathrm{C}$, with an average minimum of $14.6{ }^{\circ} \mathrm{C}$, the average maximum of $27.0^{\circ} \mathrm{C}$, and average annual rainfall of $1,350 \mathrm{~mm}$ (CEPAGRI [14]).

The CEA-IAC conducts research and provides technological services in the areas of agricultural mechanization and post harvest, and conducts studies on the impact of human activities on the environment in the experimental area that reaches 110 ha.

In the early 1960's urbanization led to a different occupation in the area. The upper part was occupied with the extraction of soil, while the top of the fourth part was occupied by gravel mining (Figure 1, points 1 and 2). The upper third of the slope, between the middle and top, was occupied by a court and making a plateau $100 \mathrm{~m}$ base and $100 \mathrm{~m}$ wide, in which a test area for tractors was constructed (Figure 1, point 3 ). In this area held a large amount of testing and evaluation of fertilizers and, related technological research activities. 
The lower of the slope was busy with a range of forest replanted Araucaria angustifolia (Figure 1, points 4-7). In the final room has an area of hydromorphic soil occupied by hydrophilic vegetation. This occupation is maintained for a period of 45 years.

\subsection{Diverse biological analysis}

For the development of the work we used a metal frame with dimension $54 \mathrm{X} 40$ $\mathrm{cm}$. Inside the box was a woven nylon mesh with spaced $6 \times 10 \mathrm{~cm}$. The intersection of nylon yarns, inside the metal frame, corresponding to a reading of the presence or absence of a particular biological activity. Therefore, from the frame placed on the surface of the sampled location, it was possible to obtain a total of 24 observations. The relationship between the number of observations of the activity of a given number of samples for a frame (24) allows to obtain a percentage of occurrence for that activity assessed.

The perception and quantification of the presence of specific biological activity was made from photographs taken perpendicular to the ground surface at a height of $1.50 \mathrm{~m}$. Through these photographs were measured the presence of litter, grasses, legumes, insects and fungi. Soon after this photographic record, withdrew from the vegetation cover, and repeat the procedure for determining the percentage of insects, fungi and roots in bare soil.

\subsection{Soil analysis}

Corresponding points in diverse biological analyzes, soil samples were collected for determination of their chemical and physical properties. The chemical analysis carried out according to the methodological aspects mentioned by Silva [15] include the following parameters: $\mathrm{pH}$, organic matter (OM), phosphorus (P), potassium $(\mathrm{K})$, calcium $(\mathrm{Ca})$, magnesium $(\mathrm{Mg})$ and sum of bases $(\mathrm{SB})$.

The textural class and soil porosity in the studied points were determined by the pipette method following the method described by Embrapa [16] and Hillel [17].

\section{Results}

The results of the description of the diverse biological activities, of each point measured in transect can be seen in Table 1.

Point 1 is characterized by a mining area and showed the worst conditions of life support, because the surface layer removal led to a lack of green vegetation cover (Table 1) and a consequent low activity of fungi and insects. This biological condition is associated with lower levels of organic matter, phosphorus, and soil moisture, as can be seen in Figure 2.

Despite its proximity to the mining area, point 2 had biological and chemical indicators comparable to those observed at points located outside the forest area. This condition demonstrates the importance of keeping the surface soil horizons of origin, as well as the vegetation cover. 
Table 1: Description of the diverse biological activities, of each point measured in transect, in Jundiaí, state of São Paulo, Brzil, in 2011.

\begin{tabular}{|c|c|}
\hline Points & Description \\
\hline 1 & $\begin{array}{l}\text { The mining area with losses of soil horizons. There was a low } \\
\text { percentage of vegetative cover on the surface, corresponding to } 5 \% \\
\text { grasses. The presence of insects reached } 14 \%\end{array}$ \\
\hline 2 & $\begin{array}{l}\text { Place situated at the apex of a hill preserving the original soil } \\
\text { horizons. The soil is completely covered by vegetation and roots, the } \\
\text { predominant litter. Minor presence of insects }(8 \%) \text { and fungus }(3 \%)\end{array}$ \\
\hline 3 & $\begin{array}{l}\text { Area located in the center of a test track tractors. Surface completely } \\
\text { covered with litter, grasses and roots, but without legumes. The level } \\
\text { of incidence of insects and fungus is the same as point } 2,8 \% \text { and } 3 \% \\
\text { respectively. }\end{array}$ \\
\hline 4 & $\begin{array}{l}\text { Araucaria forest edge next to an old terrace. Already we see the litter } \\
\text { and established species germinate in the understory. The soil has a } \\
\text { complete coverage, primarily of litter and roots, without grasses or } \\
\text { legumes. The incidence of insects increased and reached } 42 \% \text {, while } \\
\text { fungi reached } 8 \% \text {. }\end{array}$ \\
\hline 5 & $\begin{array}{l}\text { Araucaria forest with an under-canopy consists of Piperaceae and } \\
\text { some lianas, with other pines sprouting. The soil has a complete } \\
\text { coverage, primarily of litter and roots, without grasses or legumes. } \\
\text { There is a high incidence of molds }(27 \%) \text { and insect }(53 \%)\end{array}$ \\
\hline 6 & $\begin{array}{l}\text { Araucaria forest with an under-canopy consists of Piperaceae and } \\
\text { lianas, and pines sprouting. The cover features } 100 \% 100 \% \text { litter and } \\
\text { roots. The incidence of both fungus and insects reaches } 11 \% \text {. }\end{array}$ \\
\hline 7 & $\begin{array}{l}\text { Araucaria forest with an under-canopy consists of Piperaceae and } \\
\text { some vines, and pines sprouting. The cover is } 100 \% \text { and } 100 \% \text { litter } \\
\text { root, and grass }(47 \%) \text {. The incidence of insect reaches } 28 \% \text { of the } \\
\text { fungus is } 19 \% \text {. }\end{array}$ \\
\hline 8 & $\begin{array}{l}\text { Outside of the Araucaria forest, grass with high intensity }(94 \%) \text {, litter } \\
(100 \%) \text { and roots }(100 \%) \text {, but with few tree species and legumes } \\
(3 \%) \text {. Litter presents a well-defined. The incidence of insects and } \\
\text { fungus reaches } 56 \% \text { and } 17 \% \text { respectively. }\end{array}$ \\
\hline 9 & $\begin{array}{l}\text { Outside of the Araucaria forest, grass with high intensity }(100 \%) \text {, } \\
\text { litter }(100 \%) \text { and roots }(100 \%) \text {. The presence of leguminous amounts } \\
\text { to } 31 \% \text {. Introducing a litter well defined, but with few tree species } \\
\text { and a region of lowlands. There is a reduction in the incidence of } \\
\text { insect and fungus in relation to the previous point, reaching } 8 \% \text { and } \\
3 \% \text { respectively. }\end{array}$ \\
\hline 10 & $\begin{array}{l}\text { Riparian zone of hydromorphic soils and vegetation hydrophilic. Soil } \\
\text { cover is composed predominantly of roots }(100 \%) \text {, litter }(94 \%) \text { and } \\
\text { legumes }(42 \%) \text {, and grass }(14 \%) \text {. The incidence of insects and fungus } \\
\text { reaches } 14 \% \text { and } 3 \% \text { respectively. }\end{array}$ \\
\hline
\end{tabular}




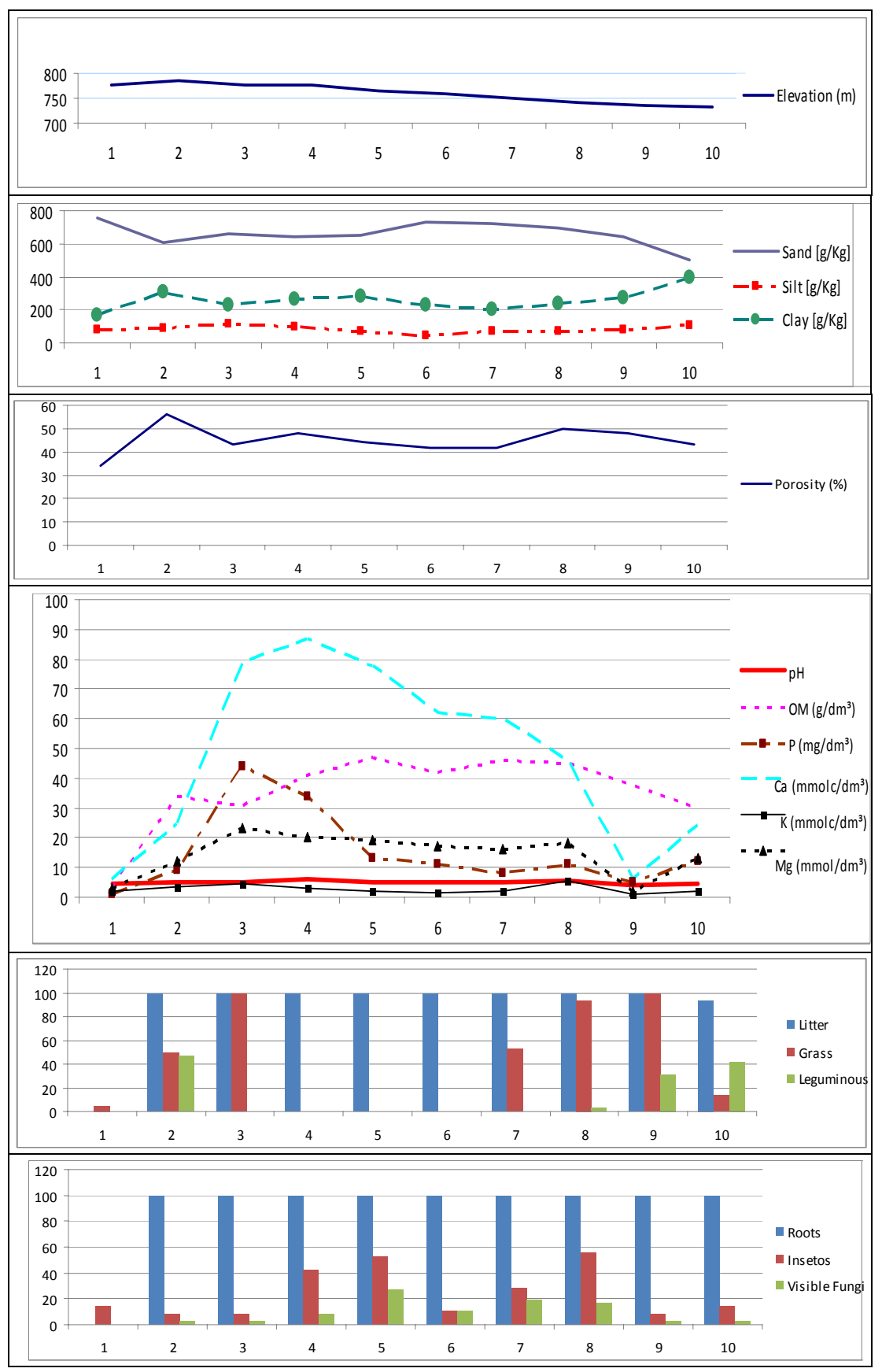

Figure 2: Graphs with the representation of points and the variables studied. 
The points located inside the forest $(4,5,6$ and 7) were those who had the highest organic matter content, ranging from 41 to $47 \mathrm{~g} . \mathrm{dm}^{-3}$, which shows the effect of this type of coverage in the recovery area. In these points were observed lower porosity, probably due the pressure caused by the root system of the trees.

This result corroborates the visual observation of the diverse biological activity at these points, mainly composed of a thick layer of litter (more than 10 $\mathrm{cm})$ and roots.

The third point is highlighted in the chemical parameters potassium, magnesium, phosphorus and calcium, because it is located within an area in which there were trials of agricultural machinery and a considerable application of chemical fertilizers for a period of over three decades.

Point 9 presented the second worst soil chemical condition, even with similar biological diversity of the forest. This singularity can be associated with geographic location of the point itself and also its proximity to a road, a situation that can express fuzzy events.

The results of texture analysis indicated that the lowest clay content reached $169 \mathrm{~g} \mathrm{~kg}^{-1}$, observed in the point 1 , probably due to removal of surface soil horizons by mining. In point 10, that of lower altitudes, there was a higher clay, reaching $392 \mathrm{~g} \mathrm{~kg}^{-1}$, suggesting that there was a deposition of alluvial material of the highest lands of the area.

\section{Final considerations}

The results showed a variation of the elements analyzed and a relationship between the use and occupation of land in the different scenarios of the current landscape. The perception of the diverse biological activity was higher in the area of Araucaria forest, showing that in 40 years of occupation the area is still recovering. Although showing relative resilience in relation to forest soil conditions, the area under pasture had a lower biological activity indicating that the area has an economic potential for farming activity. However the mining area has a low biological activity associated with physical and chemical quality of the soil. This situation confirmed a low resilience to environmental conditions within the subtropical region. Thus, the mining industry requires intervention for its recovery. This recovery can be inserted into a program of environmental management planning. Thus, through the perception of diverse biological activity was possible to characterize the different scenery of demonstrating the effectiveness of the technique to assess the level degradation in an expeditious manner and inexpensive.

\section{References}

[1] Montoya, M.A., Finamore, E.B. Evolução do PIB do agronegócio brasileiro de 1959 a 1995: uma estimativa na ótica do valor. Teoria e Evidência Econômica, 9(16), pp. 9-24, 2001.

[2] Andrade, T.A. and Serra, R.V. Cidades médias brasileiras. IPEA: Rio de Janeiro, Brazil, 2001. (In Portuguese) 
[3] Girardi, E.P. Proposição teórico-metodológica de uma cartografia geográfica crítica e sua aplicação no desenvolvimento do atlas da questão agrária brasileira. UNESP: Presidente Prudente, Brazil, 2008. (In Portuguese)

[4] IBGE (Instituto Brasileiro de Geografia e Estatística). Available on http://www.ibge.gov.br/home/ Access on March 6, 2012.

[5] Sparovek, G., Correchel, V. and Barreto, A.G.O.P. The risk of erosion in brazilian cultivated pastures. Scientia Agricola, 64(1), pp. 77-82, 2007.

[6] Peron, A.J. and Evangelista, A.R. Pasture degradation in savanna's regions. Ciência e Agrotecnologia, 28(3), pp. 655-661, 2004. (in Portuguese)

[7] Longo, R.M., Ribeiro, A.I. and Melo, W.J. Use of green fertilizing in the recovery of soils degraded by mining in the amazon forest. Bragantia, 70(1), pp. 139-146, 2011. (in Portuguese)

[8] Longo, R.M., Ribeiro, A.I. and Melo, W.J. Physical and chemical characterization of the substratum of degraded areas by tin mining. Bragantia, 64(1), pp. 101-107, 2005. (in Portuguese)

[9] Medeiros, G.A., Reis, F.A.G.V., Menezes, P.H.B.J. et al. Diagnosis at the dump area of Poços de Caldas, state of Minas Gerais, Brazil. Engenharia Ambiental, 6(2), pp. 03-15, 2009. (in Portuguese)

[10] Medeiros, G.A., Daniel, L.A., Lucarelli, J.R.F. and Reis, F.A.G.V. Influence of the soil tillage and management in a Latossolo vermelho on its physical and hydrics properties. Geociências, 28(4), pp. 453-465, 2009. (in Portuguese)

[11] Bennet, D.P. and Humpries, D.A. Ecologia de campo. H. Blume Ediciones: Madrid, Spain, 1981. (In Spanish)

[12] Maeder, P., Fliessbach, A., Dubois, D., Gunst, L., Fried, P. and Niggli, U. Soil fertility and biodiversity in organic farming. Science, 296 (5573), pp. 1694-1697, 2002.

[13] Ramesh, S. and Mathivanan, N. Screening of marine actinomycetes isolated from the Bay of Bengal, India for antimicrobial activity and industrial enzymes. World Journal of Microbiology and Biotechnology, 25(12), pp. 2103-2111, 2009.

[14] CEPAGRI (Centro de Pesquisas Meteorológicas e Climáticas Aplicadas a Agricultura) Clima dos municípios paulistas: Jundiai. Available on http://www.cpa.unicamp.br/outras-informacoes/clima_muni_296.html Access on March 21, 2012.

[15] SILVA, F.C. Análises químicas para avaliação da fertilidade do solo. Manual de análise química de solos, plantas e fertilizantes, Silva, F.C. (org.), EMBRAPA: Brasília, pp.75-166, 1999.

[16] EMBRAPA (Empresa Brasileira de Pesquisa Agropecuária). Centro Nacional de Pesquisa de Solos. Manual de métodos de análise de solo. Ministério da Agricultura e do Abastecimento: Rio de Janeiro, 1997.

[17] Hillel, D. Environmental soil physics. New York, Academic Press, 1998. $771 \mathrm{p}$. 